\title{
Different Methods of Teaching of Economic Subjects
}

\author{
Olha V. Yevtushevska \\ Taras Shevchenko National University of Kyiv
}

*Corresponding Author: Olha V. Yevtushevska, Taras Shevchenko National University of Kyiv, Ukraine

\begin{abstract}
This article dedicated to various ways of teaching for students of different courses and specialties. Ordinary re-creation of lecture material not always provides desired result. Discussion of discordant economic questions should be combined with trainings, which help to attract all audience to common work. Proposed approaches were adapted for students of economic and non-economic professions.
\end{abstract}

Keywords: Trainings, Role plays, Interesting topics, Abstract material, Motivation.

\section{INTRODUCTION}

Teaching of economic courses is rather difficult task. Students often complain about unpracticality of studying, uninteresting seminars and lectures. Teaching also reveals such problem as a feeble cooperation between lecturer and students. Protracted, abstract beginning of lectures leads to a loss of attention and interest after couple of minutes. Seminars, which are often converted into re-creation of well-known facts or on the contrary very complicated, unintelligible material, are also a trial for lecturer and students. It constrains think about teaching process improvement and make it more practical, at the same time understanding, that theory is an inevitable part of teaching.

\section{Some Methods of TeACHING OF ECONOMIC SubJects}

\subsection{Use of classical fiction in teaching}

Economic courses are often considered to be scholastic and abstractive. It is very difficult to perceive such material without vivid, interesting examples and insertions. Classical fiction can be a useful source of improvisations, jokes, witty examples, which help to comprehend material of course. For example, explaining distinctions of time-management, we can use composition of Jerome K. Jerome [1]. Some works of Mao Dun [2] can be useful for analysis of traditional economy. Contradictions between workers and capitalists are shown in compositions of Charles Dickens [3]. Main questions of economic activity can be illustrated by creation of O. Henry [4]. Types of economic negotiations are shown in work of Theodor Dreiser [5].Creating of fictitious joint-stock companies is described in creation of M. Saltykov-Shchedrin [6]. Psychological peculiarities of entrepreneurs are depicted in works of F. Dostoevsky, A. Miller, I. Shmelev etc.Such examples help to memorize material and concentrate attention on main topic of lectures without much affords. It also creates memorable connections between literature examples and economic conceptions.

\subsection{Unexpected introduction}

In our work we usually start lectures with topics and main problems of lesson. Often during these minutes students lose their concentration. It is rather difficult to renew an interest after protracted, scholastic introduction. Maybe, it would be better to start with some sudden question, concerning the topic. Such question should bea riddle for students. Only when lecturer attracted their attention he or she should proceed with the topic and main point of lesson. For example, opening theme of manipulations in economic negotiations, I usually ask students, whether they have a situations, when someone asks them, what time is now. Of course, part of audience had such experience. After that we conceive different motives of such asking. It can be a real need to know, what time is now, it can be a hidden desire to look at someone's watch to know a status of interlocutor. It even can be longing for steal the watch. Explaining theme of historical development of entrepreneurship in Ukraine in XX century, I usually question, why Bolsheviks exterminated free enterprise. It increases attention, generates discussions as to their main reasons and motives, as much as this question is not only economic, but also political, philosophical and, maybe, still difficult for descendants of persons 
subjected to repressions. Considering command economic system, we debate, why communists in Soviet Union were concentrated on world proletarian revolution. Was it only political interest or necessary condition for command economy functioning. As a rule, students have different opinions, so it leads to discussions.

Generally, such questions should be not only unexpected, but also lead to constructive discussion. Main task of lecturer in such case, besides explaining of main concepts of lesson, is to involve audience in mutual cognitive process.

\subsection{Use of interesting topics in teaching}

Economic subjects mostly consist of wide, complicated themes. Such material without interesting insertions is complex for audience. Sometimes even lecturers lose their interest to teaching because of complicated, estranged from reality material. Of course, classical theories are necessary. But we can combine them with original, vivid topics. For instance, in course devoted to state regulation of entrepreneurship, besides research of main methods and models of state regulation, we can insert topics, dedicated to enterprise in North Korea, social utopias, shadow entrepreneurship etc. Management can be enriched with analysis of art-management, management of sales and so forth. Course of marketing can be completed with research of guerrilla marketing, word of mouth marketing and neuromarketing (although last conception causes active debates).

\subsection{Training on seminars}

Sometimes seminars reduce to re-creation of lecture material. That is the most ineffective way of teaching, which deteriorates owing to unhealthy competition between students. Better approach to teaching is discussion of controversial problems. However, in this case less active students don't take part in mutual consideration. In our opinion, most effective way of studying is training. Under such conditions all students take part in joint work or at least memorize proposed material better than on ordinary lessons.

Maybe, one of the most ordinary, but memorable training is creation of advertisement. Quantity of students shouldn't exceed 20 persons. All audience is divided into small groups (4-5 persons), each of them get their own commodity or service. Articles of trade are given by lecturer, because discussions between students as to object of advertisement take a lot of time. Mainly after 25 - 30 minutes of debate each group is ready to present their advertisement. Students must make oral presentation of promotional message, create symbolic personage and describe a design of commodity (if it is possible). In our opinion, there is no need to oblige less active students make a presentation. Talented speakers will make it. Others will take part into consideration. Some groups cast roles and make an interesting plays. Of course, it is not obligatory demand. Generally, trainings and role plays cannot be a constant type of work, because it is rather tiring, although creative labor. Role plays shouldn't be tiresome and satiated [7].In our opinion, it is better to alternate trainings with usual discussions.

One more training devoted to management of sales, namely to so-called "cold" calls. Lecturer and students or only students cast roles to create a dialogue between imaginary seller and client. It is better to play first dialogue between lecturer and someone from an audience to show a rest how to hold the conversation. Primary aim of this training is to study to work with objections of potential customers. Experienced and confident pedagogue can make a real call on lesson in a role of potential client (if he or she really needs to buy something). Roles of pseudo-seller or pseudo-buyer would be unethical. During this training lecturer should remind about necessity to adhere to ethics of "cold" calls, because in reality some sellers lie to potential clients and manipulate their needs.

Next training dedicated to brands and trademarks. We have a huge amount of trade marks on a domestic market in Ukraine. Usually name of brands and trademarks generate concrete associations, combined with some values. Last ones should be directed at target audience. These values should be agreed with interests of potential consumers. For example, trademarks or brands can symbolize family values, high status, simplicity, patriotism, nostalgia, tender emotion, courage, naturalness etc. Lecturer chooses groups of 3 or 4 trademarks, united by main mutual value. Then writes a name of trademarks and asks students about one primary worth, which unite each group. Lecturer also questions listeners about target audience of these trademarks. Shortcoming of this training is trifle chaotic character of the seminar, since students usually say right answer together. So it can be difficult to estimate individual participation of each person. 
Other training devoted to corporate conflicts. Corporate conflict is one of the most vivid topics, however, in reality conflicts are not very pleasant process. This training aimed at ability to smooth over annoying problems on a working place. Of course, one lesson will not make sufficient result. But it helps to imagine conflict situation and our capability to solve or at least to soften it. Lecturer proposes to audience concrete conflict cases taken from a literature [8] or from own life experience. As a rule, when students hear some provoking, accusatory phrases, they are embarrassed. Usually two or three persons begin to answer in aggressive or sarcastic manner. But after couple of minutes students adapt themselves to situation. Some of them begin to use humor and constructive arguments. However, some cases are so difficult, that audience can't find an adequate solution. It is made on purpose to show students, that in some cases we can do nothing better than wait till the conflict is over or seek for so-called third side. Main task of this training is to show an audience, that aggression, irony, long exculpation and servility are not successful ways of corporative conflicts solution.

\section{Main Problems Of Economic Courses Teaching}

\subsection{Abstract lecture material}

Wide-spread problem of teaching is an abstract, scholastic and sometimes even obsolete educational material. Abstraction is a higher level of reality perception. However, beginners perceive every field of science by means of concrete images. Abstraction prevents from understanding and memorizing of some ideas [9].That's why it is extremely important to give many vital, bright, witty examples, which help to understand complex subject. After explanation of abstract conception lecturer should confirm it with demonstrative concrete instances. It's advisable, not only verbal, but also visual examples. Also abstract material should be maintained by short debates as to every theory. It will help to set connection with an audience.

Some of economic knowledge becomes obsolete. It doesn't pertain to basic economic disciplines and classical economic conceptions. In spite of all changes classical theories help to comprehend economic and social processes, to research society development and social perspectives. But part of material of derivative economic courses needs a recurrent renovation. Lecturer also should supplement educational material with new topics, theories, data, especially in courses, connected with innovations and scientific progress.

\subsection{Indifference to teaching}

Obviously, insensibility of lecturers is the most serious and painful problem. In our opinion, under normal condition (when human is provided with acceptable set of goods and comfort)it is very hard to motivate listless person to be a good teacher with nonmaterial stimulus, because motivation is an inner process. Under unfavorable circumstances, when material motives are dominate, such person can be motivated by salary, bonus, material goods and afterwards works better, however stiffly and, maybe, not always sincerely. The best stimulus for self-motivated lecturer is situation, when nobody impedes teaching. Often reduction of bureaucracy demands, meetings and useless beadledom are better stimulus, than career growth, rewards, title and so on.

\section{CONClusion}

Teaching is truly interesting, inspiring although a complex process. Nowadays it is very popular to talk about changes in education. Researchers and officials propose to change methods of teaching, to alter world-view principles of education or just to change duration of lessons and brakes, diversify courses or to oblige all lecturers and teachers use an innovative technologies etc. But core of the problem is considerably simpler and at the same time more complicated, because mostly success of teaching depends on lecturer skills, inspiration and pedagogical talent and, of course, on motivation of students. Maybe, the most important idea of this article - audience most likely excuses lecturer's mistakes and even peculiarity, but hardly forgives indifference of pedagogue.

\section{REFERENCES}

[1] Jerome K. Jerome Three Man in a Boat (to Say Nothing of the Dog):Znannya; (2015), 238; (Book style).

[2] Mao Dun Spring Silk-worms. Works of Chinese Classics: Fiction, (1974); (Book style).

[3] C. Dickens Hard Times: State Publishing House of Fiction ;( 1960); (Book style).

[4] O. Henri Cabbages and Kings: Publishing House of Mescheryakov; (2007); (Book style). 
[5] T. Dreiser Phantom Gold:Znannya; (2017), 223; (Book style).

[6] Saltykov-ShchedrinM. Modern Idyll: Soviet Russia; (1976), 350; (Book style).

[7] HondarevaH.V. Role Plays as a Mean of Intensification of Pupils' Cognition Activity on Lessons of Economics.Tavriyskiy Announcer of Education (41); (2013), 233 - 238 (Article).

[8] Kozlov V.V., Kozlova A.A. Conflict: to Take Part or to Create: Eksmo;(2009) (Book style).

[9] C. Heath, D. Heath (2017) Made to Stick: Why Some Ideas Survive and Others Die: Club of Family Leisure; 304; (Book style).

\section{AUTHOR's BIOGRAPHY}

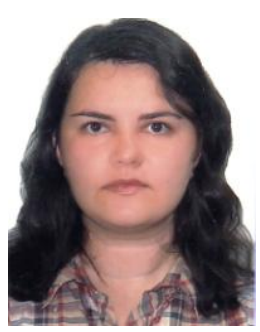

Olha V. Yevtushevska was born in Kyiv. Since 2010 I work at the Department of Enterprise, Taras Shevchenko National University of Kyiv. In 2010 I defenced a thesis "Development of corporative relations under market economy". I teach economic courses for students of different professions.

Citation: Olha V. Yevtushevska. "Different Methods of Teaching of Economic Subjects". International Journal of Humanities Social Sciences and Education (IJHSSE), vol 5, no. 1, 2018, pp. 123-126 doi: http://dx.doi.org/10.20431/2349-0381.0501019.

Copyright: () 2018 Authors. This is an open-access article distributed under the terms of the Creative Commons Attribution License, which permits unrestricted use, distribution, and reproduction in any medium, provided the original author and source are credited. 